\title{
ZUR DATIERUNG \\ DES Gg-PROLOGS ZU CHAUCERS LEGENDE VON DEN GUTEN FRAUEN.')
}

\author{
EINE HERALDISCHE STUDIE. ${ }^{2}$ )
}

In der vielumstrittenen frage der priorität der $\mathrm{Gg}(\mathrm{A})$ oder F(B)-version zu Chaucers legendenprolog (siehe Hammond. Chaucer. A Bibliographical Manual, seite 381 bis 383) ist es mir durch einen glücklichen fund gelungen, eine nach meiner auffassung entscheidende lösung herbeizuführen und der ansicht derjenigen gruppe von gelehrten zum siege zu verhelfen, die, wie von den älteren Chaucerforschern besonders Ten Brink (Engl. Studien 17, 195-200), mit guten, wenn auch keineswegs ausschlaggebenden und die gegner durchaus

1) Dem herausgeber dieser zeitschrift, herrn prof. Eugen Einenkel, den ich zuerst von den hier folgenden einzelheiten in kenntnis setzte, für seine stets bereite hilfe meinen herzlichsten dank auszusprechen, ist mir eine angenehme pflicht; auch kann ich nicht unterlassen, herrn prof. Alois Brandl - der in diesem jahre den gluckwunsch der "verehrten nnd lieben freunde", die ihm "über die schwelle der sechziger mit ermutigender güte hinweghalfen", in so tief empfundener weise erwidern konnte - ein wort des dankes zu sagen. Ist doch die von mir gern nud häufig benutzte błhchersammlung des englischen seminars in Berlin, die unter seiner regie zu einer stattlichen bändezahl angewachsen ist, sein eigenes und eigenstes werk. Mit herrn prof. Morsbach, aus dessen schule eine reihe bedentsamer einzelschriften über Chaucer hervorgegangen ist, stehe ich, ebenso wie mit herrn prof. Einenkel, seit längerer zeit in lebhaftem gedankenaustausch (siehe auch meine Rosenromanstudien in Anglia 35, 36, 37). Möge es mir vergönnt sein, von ihrem scharfen auge geleitet, noch manches jahr den spuren unseres lieblingsdichters zu folgen!

2) In meinen bei Max Niemeyer, Halle, erscheinenden 'Neuen Chaucerstudien' werde ich auch über 'Heraldisches bei Chaucer' zu handeln haben. 
nicht überzeugenden gründen,1) die Gg-version des legendenprologs als die jüngere, umgearbeitete redaktion zu erweisen suchten. Es ist nicht meine aufgabe, die argumentation Ten Brinks und seiner anhänger (Koeppel, Kaluza, Mather, Binz, Lowes, Tatlock), sowie seiner antipoden (Furnivall, Skeat, Bech, John Koch, Bilderbeck, John C. French) noch einmal aufzurollen, ich muls vielmehr den leser in allen punkten auf die interessanten ausführungen und umfassenden literaturangaben von Tatlock in den publikationen der ChaucerSociety vom jahre 1907 auf seite 86-122 seiner 'Development and Chronology of Chaucer's Works', sowie auf einen nemeren kleinen aufsatz von Bernard L. Jeffreson: Queen Anne and Queen Alcestis im Journal of English and Germanic Philology vom Juli 1914, vol. XIII, no. 3 (seite 434-443) verweisen. An dieser stelle will ich nur versuchen, einen kurzen bericht über meine entdeckung zu geben, die, wie wir sehen werden, zum ersten male eine sichere schlufsfolgerung zuläIst.

\section{I.}

In dem F-prolog trägt der liebesgott als zeichen seiner königlichen würde eine sonnenkrone. Dort heilst es, vv. $226 \mathrm{ff}$.:

Y-clothed was this mighty god of Love

In silke, enbrouded ful of grene greves,

In-with a fret of rede rose leves,

The fresshest syn the worlde was first bygonne.

His gilte here was corowned with a sonne...

Im Gg-prolog dagegen hat Cupido:

'a garlond on his hed of rose levys,

stekid al with lylye flourys newe ( $\nabla \nabla .160 / 161)$.

Das ist sehr bezeichnend. Da im Roman de la Rose, aus dem Chaucer bekanntlich einige konventionelle züge für die gestalt seines liebesgottes entlehnt, Cupido auch nur 'ot

1) Man vergleiche besonders John Kochs rezension von Legouis: Quel fut le premier composé par Chaucer des denx prologues de la Légende des Femmes Exemplaires? (Engl. Stud. 30, s. 456-458), in der die behauptung aufgestellt wird, dafs "durch die darlegungen des herrn Legouis (dieser entscheidet sich für die $F^{\prime}(B)$-version als spätere fassung) die frage des verhältnisses der beiden prologe zu einander endg ültig entschieden sein dürfte". 
au chief un chapelet de roses' (vv. 889/90), so erhebt sich die frage: warum erscheinen in der Gg-fassung des prologs gegenüber der F-version in verbindung mit den rosen lylye flourys ${ }^{1}$ ) newe? Wie ist diese auffällige redaktionelle änderung des dichters zu erklären? Auf diese frage ist m. e. nur eine einzige antwort möglich. In der erwähnung der lilien, mit denen sich der liebesgott im Gg-prolog im verein mit rosen schmückt, liegt zweifellos eine anspielung auf die fleurs-de-lis im wappen der könige von Frankreich. Wir wissen, dals könig Richard II von England nach dem tode seiner ersten gemahlin Anna von Böhmen sich 1396 formell ${ }^{2}$ ) mit Isabella, der tochter Karls VI von Frankreich, vermählte, siehe John of Gaunt. By Sidney Armitage-Smith, Westminster, 1904, s. 396: 'In the Church of St. Nicholas at Calais, on Saturday, November 4 (1396), the Archbishop of Canterbury married the King of England to the daughter of his hereditary adversary.'

Einen kranz von rosenblättern auf dem haupte, die mit neuen lilienblumen ganz "besteckt" sind (cf. Webster, English Dictionary: to stick, 'to be united closely'), so tritt uns im Gg-prolog der gott der liebe entgegen: ein deutlicher symbolischer hinweis auf Richard II, der die häuser Valois und Plantagenet 'by the bonds of a blood alliance' (John of Gaunt, by S. Armitage-Smith, s. 395) vereinigen sollte.

Können wir aber den worten 'Stekid al with lylye flourys newe' nicht noch einen tieferen sinn unterlegen? In den mir bekannten heraldischen nachschlagewerken wird übereinstimmend berichtet, dafs könig Edward III von England im wappenschilde lilien geführt habe, und zwar in willkürlicher, beliebiger zahl: ("bestreut", um den heraldischen ausdruck zu gebrauchen); vergleiche Berry, Encyclopaedia heraldica, vol. 1, sub 'Arm, Saxon Line Restored': Arms-quarterly, 1st and 4th, France, viz. az. semée of fleurs-de-lis or: $2 d$ and $3 d$ England, gu. three lions passant guardant or. Nach Siebmacher, grolses und allgemeines Wappenbuch, herausg. von

1) In der von Chaucer im legendenprolog benutzten stelle aus dem Roman de la Rose, $\nabla \nabla .867 \mathrm{ff}$., wird unter den 'flors de maintes guises', v. 881, die lilie nicht genannt.

$\left.{ }^{2}\right)$ Bekanntlich ist die vermählung bei der jugend Isabellas und Richards II frühem tode (1400) nie vollzogen worden. 
dr. Otto Titan von Hefner. Nürnberg 1857. 1. band, 2. abteilung, seite 17 zeigen "die beiden ersten siegel Edwards III nur den schild mit den drei löwen, auf dem 3. siegel aber erscheint zum ersten mal der schild geviertet mit dem wappen von Frankreich und England." Da die ansprüche ${ }^{1)}$ Edwards III auf Frankreich nicht sogleich anerkannt wurden, hatte er feierlich titel und wappen eines königs von Frankreich angenommen (Siebmacher, loc. cit. s. 17). Auch Richard II 'used the same arms as his grandfather, Edward III, upon his Great Seal'. Der zusammenhang ist somit klar. Wie Edward III als der erste könig von England von seiner mutter Isabella, der tochter könig Philipps IV von Frankreich, die berechtigung zur führung der französischen 'semée of fleursde-lis' im wappen Englands herleitete, so besals sein enkel und nachfolger Richard II von England durch seine vermählung mit Isabella, der tochter könig Karls VI von Frankreich, ein erneutes ${ }^{2}$ ) anrecht, die französische wappenblume in seinem wappenfelde $\mathrm{zu}$ haben.

Der ausdruck im Gg-prolog "ganz mit neuen lilienblumen besteckt" erscheint als vom dichter mit absicht gewählt und enthält eine durchsichtige anspielung auf ein bedeutsames geschichtliches ereignis. ${ }^{3}$ ) Die Gg-redaktion des legendenprologs kann von Chaucer erst nach dem 4. November 1396 (als terminus a quo) verfalst worden sein, und die anspielungen auf das hohe alter Chaucers, die sich bekanntlich nur im Ggprolog finden, erhalten durch diese sichere datierung erhöhte bedeutung, da, wie wir jetzt wissen, der F-prolog (der nach Lowes' genauer fixierung 4) im jahre 1386 entstanden ist) und der Gg-prolog um zehn volle jahre auseinanderliegen.

1) cf. Berry, l. c. sub Arm. Saxon Line restored: Edward III assumed the title of King of France, in right of his mother Isabel, daughter of Philip IV. King of France, the three sons of Philip (Lewis, Philip, and Charles, successively Kings of France) dying without issue.

2) stekid al with lylye flourys newe.

$\left.{ }^{3}\right)$ John of Gaunt. By S. Armitage-Smith, seite 395: 'With feelings of unmixed satisfaction Lancaster left England, in October, 1396, to arrange the formalities of that meeting between the two Kings which was to inaugurate a new period of peace, and nuite the Houses of Valois and Plantagenet by the bonds of a blood alliance.'

^) Vergleiche hierzu Tatlock, Publ. Ch. Soc. 1907, seite 122. 
II.

Im vorhergehenden habe ich mich gelegentlich auf das nicht nur dem historiker zu empfehlende werk von S. ArmitageSmith über John of Gaunt, den herzog von Lancaster, berufen können. Wir werden diesem buche, das unter gründlichster benutzung der quellen ein lebensvolles bild von der zeit und dem charakter des "Seneschal of England" zeichnet, einen weiteren wichtigen aufschlufs zu verdanken haben, der um so wertvoller ist, als uns Deutschen infolge des krieges die schätze des British Museum nicht mehr zugänglich sind.

Die geschichte der heraldik lehrt uns, dafs neben den eigentlichen wappenfiguren sogenannte "badges", 1) d.h. persönliche abzeichen der könige einhergehen. In den illustrationen, die Sidney Armitage-Smith seinem werke beigibt (sie sind nach handschriftlichen vorlagen aus dem British Museum gefertigt 2)), ist eine ziemlich grofse auslese solcher "badges" konig Richards II, des letzten der Plantagenets, zu finden. Wie mir der bekannte heraldiker, kammerherr dr. jur. et phil. Stephan Kekule von Stradonitz, bestätigt, handelt es sich bei einem dieser abzeichen, die wir auf den gobelins oder wandteppichen deutlich zu erkennen vermögen, zweifellos um stilisierte ginstersträucher, the "broom-plant, or planta-genista, a sprig of which was always worn in the cap of the great ancestor of the family, Geoffroy le Bel; from which circumstance is said to be derived its name of Plantagenet" 3) (Fairholt's Costume in England. vol. 1. H. A. Dillon. S. 122 almerkung).

1) Zur erklärung des ausdrucks "badges" vergleiche man Siebmacher, 1. c. s. 18: "Der wille eines wappenherrn erkor sich eine dieser figuren (bald waren es sicheln, äste, blumen, ganze tiere oder teile davon), und man wendete sie aller orten an, auf kleidern, pferdedecken, in siegeln und glasgemälden."

2) Siehe Illustrations, seite 404: "The Banishment of the Dukes of Hereford and Norfolk", from British Musenm, Harl. MS. 4380, f. 148 und seite 348: "Signature of a Truce", from British Museum, Harl. Ms. 4380, f. 11.

3) cf. Dictionary of National Biography, sub "Plantagenet": Plantagenet was originally - under the form Plante-geneste - a personal nickname of Geoffrey, Count of Anjou, father of Henry II [Wace, Roman de Rou]. Man vergleiche auch die weiteren ausführungen im D. N. B. 
Vergleichen wir jetzt mit diesem kulturhistorisch bedeutsamen funde die darstellung unseres dichters im legendenprolog F 226 ff. und Gg 158/9. Dort ist das seidene gewand Cupidos "bestickt mit grene greves", was doch nichts anderes heilsen kann als grüne sträucher,1) eine bedeutung, die klärlich auch Troil. a. Cr. V, 1144 vorliegt. Zwar sagt Skeat in seinen Notes zur Legende of Good Women, v. 227: 'Greves is properly groves or bushes, but must here mean sprays or small boughs', doch zweifle ich sehr, ob diese in nicht ganz sicherem tone vorgebrachte auslegung des englischen gelehrten richtig ist. Nach der ansicht des herrn professor A. M. Hildebrandt, abteilungsvorstandes für wappenkunde im verein Herold zu Berlin, konnten königsgewänder sehr wohl mit stilisierten sträuchern bestickt sein.

'In-with a fret of rose leves', F-prolog v. 228 - 'a garlond on his hed of rose levys', Gg-prolog v. 160. Sind die hier erwähnten rosen ebenfalls "badges" könig Richards II? Sie sind es in der tat, wenn man der darstellung Siebmachers (loc. cit. s. 17), der sich auf ein nach einem "altenglischen" muster gezeichnetes wappen des königs bezieht, $\left.{ }^{2}\right)$ glauben schenken darf: Die helmdecken sind aufsen rot mit goldenen rosen besät, innen hermelin. Die letztere art heraldischen luxus war in England sehr in schwung, und es finden sich nicht blofs bei den wappen des königlichen hauses, sondern auch bei sehr vielen anderen altenglischen geschlechtern, die mit hermelin gefïtterten helmdecken. Ebenso häufig ist die bestreuung oder besäung der aufsenseite der helmdecken mit kleinen wappenfiguren, wie hier die goldenen rosen, welche zugleich mit dem rot der aufsenseite die eigentlichen wappenfarben kundgeben sollen." A golden rose stalked proper war ein 'badge' Edwards I (Boutell, English Heraldry, s. 235).

Als das letzte abzeichen des liebesgottes begegnet im F-prolog v. 230 (nicht im Gg-prolog) die sonne, die wiederum als abzeichen könig Richards II anzusehen ist. Das prachtvoll ausgeführte 'badge of Richard II from Ms. Vincent 152 at

1) Nach dem New English Dictionary ist greenweed 'the plant genista tinctoria' (Färberginster).

2) Abgebildet auf tafel 35 des buches. 
the Herald's College' ') in dem 'Illustrated Catalogue of the Heraldic Exhibition, Burlington House, 1894. London 1896 (Plate XXX)' durfte ich in der bibliothek des vereins Herold zu Berlin 2) bewnndern. Herr professor Adolf Mathias Hildebrandt hatte die güte, mich auf den 'Illustrated Catalogue', als auf ein sehr seltenes kunstexemplar, aufmerksam zu machen. Die darstellung der heraldischen sonne als eines 'human face surrounded by rays' (Nason, Heralds and Heraldry, New York, 1907) stimmt nicht schlecht $\mathrm{zu}$ der schilderung Chaucers, F, v. 230.

Fassen wir noch einmal die angaben Chaucers im legendenprolog $\mathrm{F}$ zusammen, so sehen wir, dafs der liebesgott gekleidet ist in seide, die mit grünen sträuchern in stickerei besetzt ist, mit einem schmuck ${ }^{3}$ ) von roten rosenblättern. Sein goldenes haar ist gekrönt mit einer sonne. Dies alles sind urkundlich bezeugte badges Richards II. Wer aber noch den geringsten zweifel an der authentizität der von mir vorgelegten dokumente hegt, der lese die schilderung in Fairholt's Costume in England (vol. 1. H. A. Dillon, seite 122 und 123) nach, die aufs schönste meine deutung bestätigt und vortrefflich in den rahmen des ganzen paist: His effigy, and that of his queen, Anne of Bohemia, in Westminster Abbey, are remarkable for the costly splendour of their habiliments, and the evident accuracy of the portraiture. The exceding splendour of the dresses is, however, the most remarkable point for consideration. They are embroidered all over with the royal badges and devices, and decorated with rich and elaborate borders. The letters $R$ and $A$ together, his badges of the white hart crowned and chained, the sun emerging from a cloud, and the broom-plant, cover the entire dress .... They are much the finest examples we possess of the fashion of embroidering the dress with heraldic insignia. $\left.{ }^{4}\right)$

1) Die strahlende sonne, "the sun in his glory", um den heraldischen ausdruck zu gebrauchen. Nach Boutell, English Heraldry, London 1899, seite 235, hat Richard II nicht nur 'the Sun clouded', sondern auch 'the Sun in splendour' als royal badge.

2) Königliches Kunstgewerbe-Museum.

3) oder einfassung, umsäumung, randverzierung (border of embroidery).

-) Vergleiche dazu auch die notiz bei Lowes, Publ. Mod. Lang. Assn. XXIII, 296: "The robes of the king (Richard II) are powdered or strewn with three badges: the white hart, the broom-plant, and the rising sun.' 
The famous portrait of Richard II, in Westminster Abbey, is another fine example of the usual dress of a monarch, who, with his courtiers, seems to have set no bounds to extravagance in clothing.

His dalmatic in this picture is embroidered all over with roses ${ }^{1}$ ) and the letter $R$.

Wir kommen zum schlufs : Die tatsache, dafs Chaucer im legendenprolog den liebesgott mit den abzeichen Richards II, seines königs, schmückt, offenbart uns schlagend aufs neue, dals der dichter der historischen gestalt Richards II intime, persönliche züge entliehen hat. ${ }^{2}$ ) Ich bin auch geneigt, eine stelle des Gg-prologs, über die meines wissens alle anderen gelehrten als vermutlich für die identifizierung belanglos hinweggelesen haben, in diesem sinne $z u$ deuten. Steht doch die starke betonung der strahlenden schönheit Cupidos im Gg-prolog, ${ }^{3}$ ) vv. 163/4:

For sekyrly his face schon so brighte

That with the $\mathrm{glem}$ ) a stonede was the syhte

in vollkommenem einklang mit den angaben eines zeitgenossen Chaucers, des Adam de Usk, wonach der könig für einen der schönsten männer seiner zeit gegolten haben muls. Vergleiche Chronicon Adæ de Usk. By Thompson, London 1904, seite 1: Ricardus, Edwardi principis Wallie, filius, .... inter omnes mortales ac si secundus Apsalon pulcherrimus, sowie die notiz bei S. Armitage-Smith, John of Gaunt, s. 120: Even in his tender youth the king seems to have possessed the strange

1) Die rose findet sich auch bei Edward III; cf. Lowes, Publ. Mod. Lang. Assn. XXIII, 293: 'The Roll commences with a list of plate belonging to the king, some articles of which were marked with the Arms of England and France quarterly; others with a leopard, others with a fleur-de-lis, others with a rose.'

2 ) Eine bemerkung von Fansler, Chaucer and the Roman de la Rose, New York, 1914, seite 71 unten, "dals die ansprtiche anf die identifizierung des liebesgottes mit könig Richard II im legendenprolog von L ow es (Pabl. Mod. Lang- Assn. XIX) geschickt widerlegt worden seien", habe ich bereits in der Dtsch. Literaturzeitung vom 14. Aug. 1915 gelegentlich einer besprechung dieses buches gebührend zurückgewiesen.

3) Nicht so im F-prolog, vv. 232/3.

) cf. N. E. D.: glem, 'radiant beauty'. 
beauty of the Plantagenets, ${ }^{1}$ ) and eye-witnesses described the child dressed in white robes symbolical of his innocence as "faire among men as another Absalon".

Was Emil Meyer, die Charakterzeichnung bei Chaucer, Morsbach's Studien XLVIII, ${ }^{2}$ ) seite 32 , über die zeichnung des "ritters" im allgemeinen prolog sagt, gilt auch hier: Es "bestätigt ein rein auf grund" handschriftlicher und kulturhistorischer ${ }^{3}$ ) tatsachen "geführter beweis die durchaus wirklichkeitsgetreue behandlungsweise, die fast überall bei Chaucer in die augen springt".

(Fortsetzung folgt.)

Anmerkung des verfassers: In einem zweiten artikel werde ich der grundfrage, ${ }^{4}$ ) warum Chaucer den F(B) - prolog geändert habe, weiter nachgehen. Mit Tatlock braucht der Gg-prolog nicht gerade als eine 'rededication' gefafst zu werden. Ich bin vielmehr der ansicht und in diesem punkte finde ich die zustimmung von herrn prof. Morsbach -, dals Chancer nach der wiedervermählung des königs a us taktgefühl manches geändert hat. - Die späte abfassung von $\mathrm{Gg}$ (A) wird nach einer mitteilung von herrn prof. Morsbach auch bestätigt durch Klee, das Enjambement bei Chaucer, diss. Halle, 1913, s. 65.

1) cf. Dict. Nat. Biogr. Richard II, soite 156: With the pleasure-loving temperament, which he inherited from the 'Fair Maid of Kent' along with her physical beauty....

2) Die hübsche arbeit wird von mir demnächst in der D. Lit.-Zeitg. besprochen werden.

3) Bei Meyer, s. 32: "historischer tatsachen".

4) Hammond. Chaucer. A. Bibliogr. Manual, s. 382.

Berlin-Weissensee, im Algust $1915 . \quad$ H. Lange. 